\title{
Improvement of physical and chemical properties of concrete with brazilian silica rice husk (SRH)
}

\section{La mejora de propiedades físicas y químicas de hormigón con silice de cáscara de arroz (SRH) brasileña}

\author{
Fernanda Giannotti da Silva*1, Jefferson B. L. Liborio**, Paulo Helene*
}

* U niversity of São Paulo, São Paulo-SP, BRAZIL
** U niversity of São Paulo, São Carlos-SP, BRAZIL

Abstract
Fecha de recepción: 20/ 01/2008 Fecha de aceptación: 20/03/2008 PAG. 18 - 25

The use of industrial and agricultural waste substitutions for Portland cement has greatly contributed to sustainable development practices. The increase in cement demand will be met by the use of supplementary cementing materials, in order to minimize the clinker consumption. In this study, the effects of silica extracted from rice husk (SRH) as a partial replacement of cement in concretes with low water/binder are reported. The properties investigated include compressive strength, splitting tensile strength, water absorption by immersion, water absorption by capillarity and resistance to chloride ion penetration. The research indicates that SRH is an effective mineral addition for designing durable concrete presenting an optimal performance when the replacement ratio of Portland cement is around $10 \%$.

Keywords: Rice husk silica, concrete, compressive strength, choride ion penetration

Resumen

El uso de desechos industriales y agrícolas como segmento en la producción de cemento Portland ha contribuido de manera importante en la práctica de desarrollo sustentable. El aumento en la demanda de cemento coincide con el uso de materiales aglomerantes suplementarios para minimizar el consumo de clinker. En este estudio, se informan los efectos de la sustitución parcial de cemento Portland por sílice extraído de la cáscara de arroz (SRH) en hormigones con baja relación agua/materiales cementicios. Las propiedades investigadas incluyen resistencia a la compresión, resistencia a la tracción, absorción de agua por inmersión, absorción de agua por capilaridad y resistencia a la penetración de iones de cloruro. La investigación indica que SRH es una adición mineral eficaz para el diseño de hormigones durables que presenta una actuación óptima cuando la proporción del reemplazo de cemento de Portland está alrededor de $10 \%$.

Palabras Clave: Sílice de cáscara de arroz, hormigón (concreto), resistencia a la compresión, penetración de iones de cloruro

\section{Introduction}

O rdinary Portland cement is acknow ledged as the major construction material throughout the world. The production rate is approximately 2.1 billion tons/year, and is expected to grow exponentially to about 3.5 billion tons/year by 2015 (Coutinho, 2003). In Brazil, 45 million tons were produced in 2006. Most of the increase in cement demand will be met by the use of supplementary cementing materials, in order to reduce the green gas emission (M etha, 1994; Bentur, 2002).

Industrial wastes, such as blast furnace slag, fly ash and silica fume are being used as supplementary cement replacement materials and, recently, agricultural waste are also being used as pozzolanic materials concretes, such as silica from rice husk and rice husk ash (Liborio, 2000; Sensale, 2006). W hen pozzolanic materials are incorporated to concrete, the silica present in these materials reacts with the calcium hydroxide released during the hydration of cement and forms additional calcium silicate hydrate (C-S-H), which improves durability and the mechanical properties of concrete (Malhotra et al., 1996; Igarashi et al., 2005).

\footnotetext{
${ }^{1}$ Autor de correspondencia / Corresponding author:

Av. Prof. Almeida Prado, trav 2 no 83, São Paulo - SP - CEP: 05508-900. Brazil. Phone: 11-30915248, E-mail: fergiann@yahoo.com.br
} 
In Brazil, the rice husk volume produced in the paddy milling process is high, and represents $51 \%$ of South America production. Part of this husk is used as a source of energy (fuel) in the paddy milling process itself, generating a huge volume of ash. The ash, which has no useful application, is usually dumped directly in the environment and causes pollution and air contamination. Thus, the use of by-products is an environmental-friendly method of disposal of large quantities of materials that would otherwise pollute land, water and air.

The aim of the present investigation is to evaluate SRH as supplementary cementitious materials with reference to mechanical and durability properties of hardened concretes. In the first phase, the chemical composition, physical properties and characterization of SRH were carried out. In the second phase, studies on concrete specimens were conducted, such as compressive strength, splitting tensile strength, water absorption by immersion, water absorption by capillarity and resistance to chloride ion penetration.

\section{Experimental program}

\subsection{Material used}

For the production of concretes, the following materials were used: high early-strength Portland cement (CP V ARI, similar to ASTM C150); natural quartz sand with $2.4 \mathrm{~mm}$ maximum particle size and 2.03 fineness modulus; coarse aggregate of basaltic origin with $9.5 \mathrm{~mm}$ maximum particle size and 5.29 fineness modulus and silica from rice husk (SRH), added as partial cement replacement material (5\% and 10\%).

The SRH was produced in laboratory. The rice husk is immersed into an acid solution, followed by washing in water until the $\mathrm{pH}$ of the solution becomes neutral. After being dried, the husk is burnt, ground to required fineness and burnt again at a temperature of $600^{\circ} \mathrm{C}$, which makes the product white and amorphous (Figure 1). It is important to emphasize that the silica properties depend on burning time, temperature, cooling time and grinding conditions.

The desired consistency of the different compositions was obtained with the aid of a same percentage of superplasticizer (modified carboxylic ether) according to ASTM C 494.

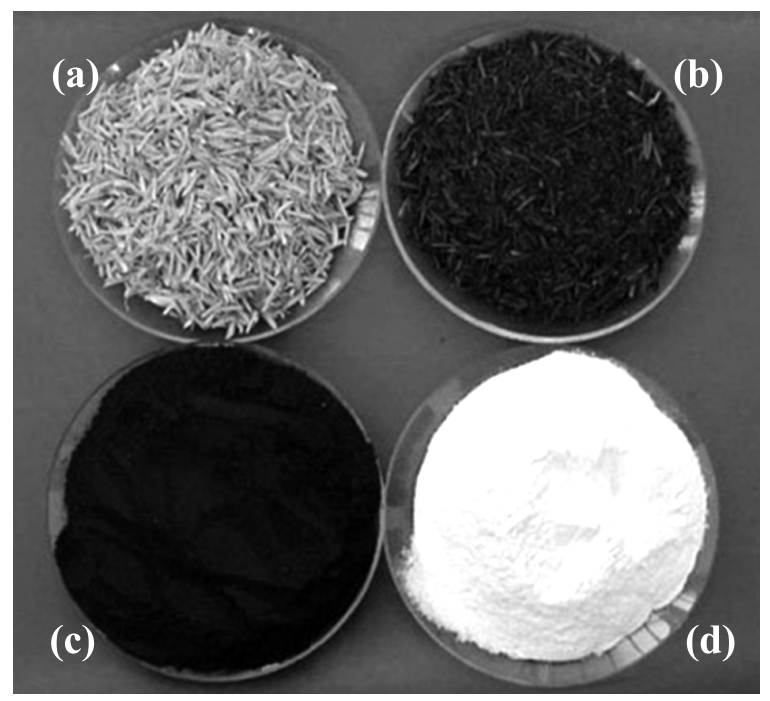

Figure 1. Phases of silica from rice husk production: rice husk (a), rice husk ash before (b) and after (c) of grinding and silica from rice husk (d)

2.2 Physical and chemical analysis of cement and SRH Mineralogical analysis of SRH was carried out by diffraction analysis. Specific surface area of cement and SRH were obtained using BET's air permeability apparatus and physical properties such as specific gravity and specific surface were determined following ASTM standards. The chemical analysis of cement and SRH also were carried out. The cement pastes reference and with SRH were used to determine the initial and final setting in accordance with ASTM C191.

\subsection{Mix proportions of concrete specimens}

The cement/dried total aggregates ratio in this work was 1:3.5. The concrete composition used in this research is presented in Table 1.

Table 1. Mixture proportions and fresh concrete properties

\begin{tabular}{||l|c|c|c||}
\hline \multirow{2}{*}{} & \multicolumn{3}{|c|}{ Concrete } \\
\cline { 2 - 4 } & Control & SRH5 & SRH10 \\
\hline Cement $\left(\mathrm{kg} / \mathrm{m}^{3}\right)$ & 503.3 & 477.1 & 451.4 \\
Rice husk silica $\left(\mathrm{kg} / \mathrm{m}^{3}\right)$ & - & 17.5 & 35.0 \\
Total water $\left(\mathrm{kg} / \mathrm{m}^{3}\right)$ & 176.2 & 167.0 & 170.2 \\
Superplasticizer $\left(\mathrm{kg} / \mathrm{m}^{3}\right)$ & 2.52 & 3.9 & 5.84 \\
Coarse aggregate $\left(\mathrm{kg} / \mathrm{m}^{3}\right)$ & 792.7 & 789.5 & 798.9 \\
Sand $\left(\mathrm{kg} / \mathrm{m}^{3}\right)$ & 968.8 & 966.7 & 965.5 \\
Water $/$ binder ratio & 0.35 & 0.35 & 0.35 \\
Fresh density $\left(\mathrm{kg} / \mathrm{m}^{3}\right)$ & 2432 & 2418 & 2400 \\
\hline
\end{tabular}


The concrete was mixed in a laboratory drum mixer for a total of three minutes. After mixing, $100 \mathrm{~mm}$ diameter $x 50 \mathrm{~mm}$ thick cylindrical specimens were cast from each mix for compressive strength, splitting tensile strength and water absorption, and $100 \mathrm{~mm}$ diameter $\mathrm{x}$ $50 \mathrm{~mm}$ thick cylindrical specimens were cast for chloride penetration test. After casting, all specimens were left covered in the casting room for $24 \mathrm{~h}$ and then demolded and transferred to a moist curing room $\left(23 \pm 2^{\circ} \mathrm{C}\right.$ and $\mathrm{RH}>95 \%$ ) until the time of the test.

\subsection{Tests}

The compressive strength of concretes was determined after 1, 3, 7, 28, 63 and 91days moist curing, as specified by ASTM C39. The splitting tensile strength test was conducted on concrete cylinders after 28 days of moist curing according ASTM C449.

Percentage of water absorption is a measure of the pores volume or porosity in hardened concrete, which is occupied by water in saturated conditions. Water absorption by capillarity values of concrete specimens after 7 and 28 days of moist curing were measured. Coefficient of water absorption is suggested as a measure of permeability of water. This is measured by rate of absorbed water by dry concrete in a period of 3, 6, 24, 48 and 72 hours (ASTM C 1585).

The resistance to chloride ion penetration in terms of charge passed values through concrete specimens after 7 and 28 days moist curing were measured as per ASTM C 1202. The positive reservoir of the cell was filled with $0.3 \mathrm{M} \mathrm{NaOH}$ solution, while the negative reservoir was filled with $3 \% \mathrm{NaCl}$ solution. A DC potential of $60 \mathrm{~V}$ was applied across the specimens faces, and the current was recorded at every $30 \mathrm{~min}$ interval, covering a total period of $6 \mathrm{~h}$. By knowing the current and time history, the total charge passed through the specimen was computed by the following formula:

$$
Q=\left(I_{0}+2 I_{30}+2 I_{60}+\ldots+2 I_{300}+2 I_{330}+I_{360}\right)
$$

where $\mathrm{Q}$ is the total passed (coulombs), 10 is the current immediately after voltage is applied (amperes), $I_{t}$ is the current at time after voltage is applied (amperes). Compatible with the charge passed, the chloride ion penetration risk of concretes is established (Table 2).
Table 2. Chloride ion penetration risk following ASTM

\begin{tabular}{|c|c|}
\hline Charge passed (C) & Risk of penetration \\
\hline$>4000$ & High \\
\hline $2000-4000$ & Moderate \\
\hline $1000-2000$ & Low \\
\hline $100-1000$ & Very low \\
\hline$<100$ & Negligible \\
\hline
\end{tabular}

\section{Results and discussion}

3.1 Physical and chemical analysis of cement and SRH Mineralogical analysis of SRH carried out by $X$-ray diffraction is shown in Fig. 2. The material consists essentially of an amorphous silica structure.

The morphology of SRH was verified by scanning electronic microscopy and compared with the microscopy of silica fume (SF). It was observed that SRH is extremely finer and their particles are lengthier than $\mathrm{SF}$, needing larger amount of water to maintain the same workability of concretes with SF (Figure 3).

The physical and chemical characteristics of cement and SRH are compared in Table 3.

The specific surface area of SRH is found to be higher than that of Portland cement and the specific gravity is found to be lesser than that of Portland cement. The chemical analysis data indicate that SRH has four times higher silica content than Portland cement.

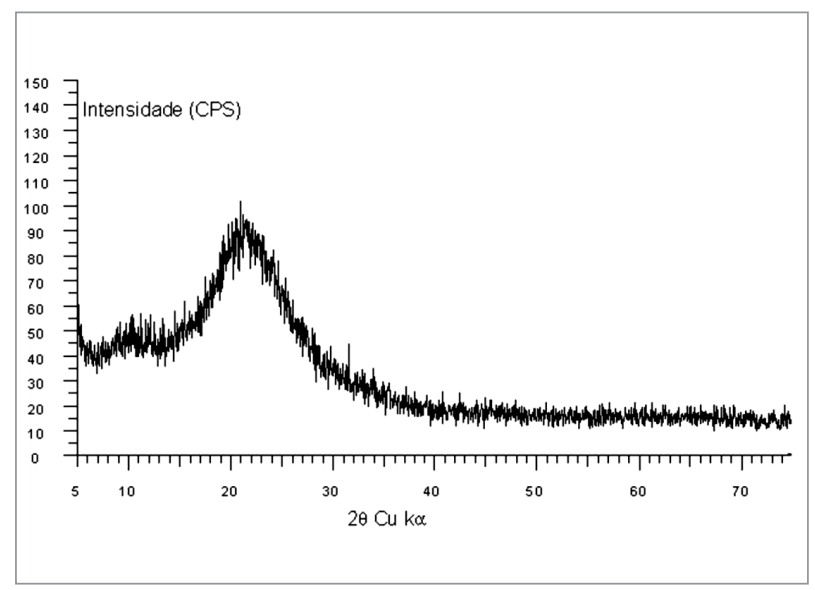

Figure 2. X-Ray diffraction of SRH 

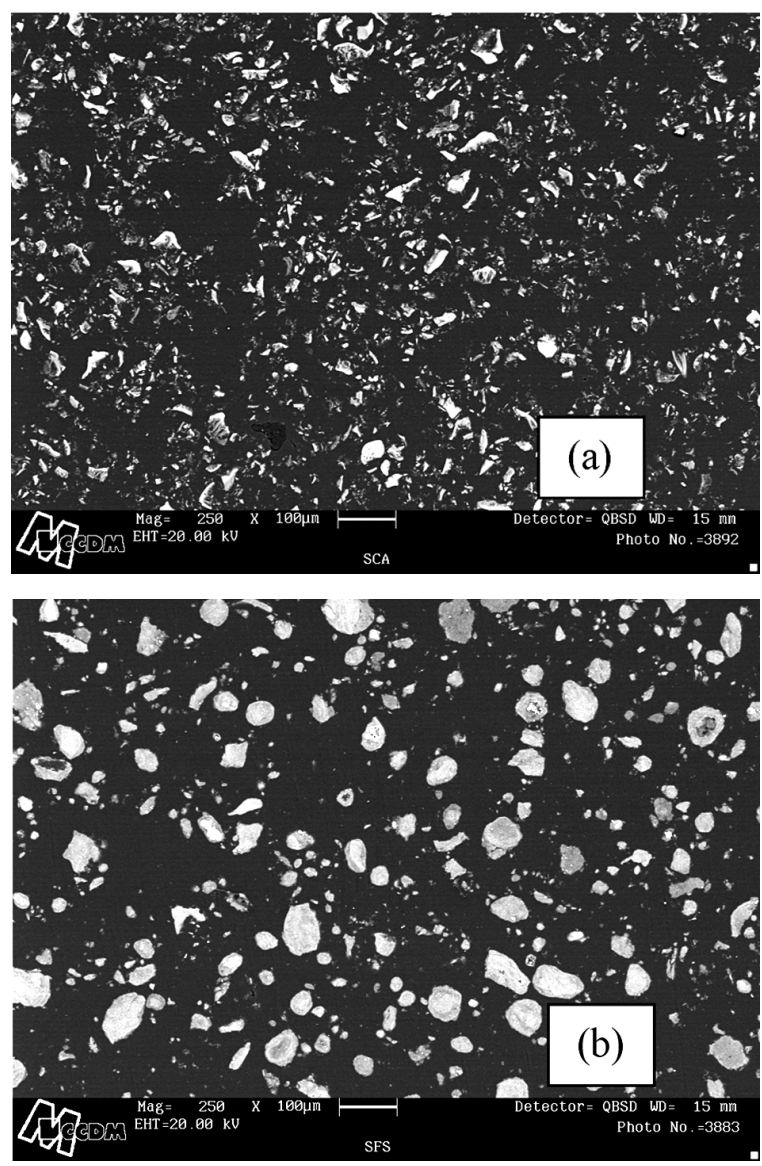

Figure 3. SEM micrograph: a) Silica from rice husk and b) Silica fume

Table 3. Physical and chemical characteristics of cement and $\mathrm{SRH}$

\begin{tabular}{|lcc||}
\hline & Portland cement & SRH \\
\hline Physical tests & & \\
Specific gravity $\mathrm{kg} / \mathrm{dm}^{3}$ & 3.10 & 2.2 \\
$\mathrm{BET}-$ specific surface $\left(\mathrm{m}^{2} / \mathrm{g}\right)$ & 0.44 & 93.6 \\
& & \\
Chemical composition & & \\
$\mathrm{SiO}_{2}(\%)$ & 21.16 & 97.53 \\
$\mathrm{Fe}_{2} \mathrm{O}_{3}(\%)$ & 1.89 & 0.21 \\
$\mathrm{Al}_{2} \mathrm{O}_{3}(\%)$ & 4.71 & - \\
$\mathrm{CaO}(\%)$ & 68.08 & 0.22 \\
$\mathrm{P}_{2} \mathrm{O}_{5}(\%)$ & 0.28 & 0.26 \\
$\mathrm{MgO}(\%)$ & 0.48 & - \\
$\mathrm{Na} 2 \mathrm{O}(\%)$ & 0.29 & 0.01 \\
$\mathrm{~K}_{2} \mathrm{O}(\%)$ & 0.48 & 0.04 \\
Loss on ignition & 2.39 & 1.72 \\
Insoluble residue & 0.81 & - \\
& & \\
\hline \hline
\end{tabular}

3.2 Setting time of blended cement The percentage of cement replacement content versus initial and final setting time chart (Figure 4) shows that even increasing the SRH content decreases the initial and final setting time.

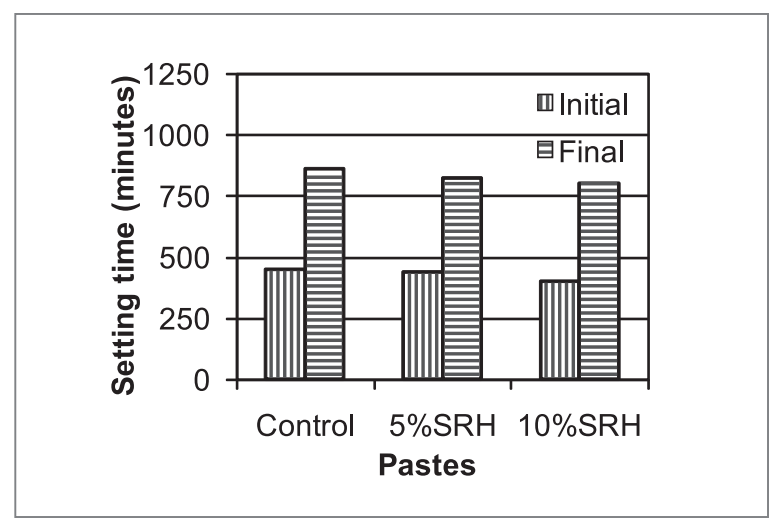

Figure 4. Initial and final setting times of pastes with and without $\mathrm{SRH}$

The initial setting time measured for $0 \%$ and $10 \% \mathrm{SRH}$ is found to be $450 \mathrm{~min}$ and $400 \mathrm{~min}$, respectively. The final setting time measured for $0 \%$ and $10 \% \mathrm{SRH}$ is found to be $860 \mathrm{~min}$ and $800 \mathrm{~min}$, respectively. This behavior can be similar to an accelerated effect, but in fact, could be explained as a filler effect, closing the grains and indicating initial and final setting reducing time.

\subsection{Compressive strength}

The compressive strength values of concrete with and without additions are shown in Table 4 and compressive strength evolution in Figure 5 . The reference specimen was prepared with $100 \%$ Portland cement and was used for comparison with the concretes with SRH (5 and 10\%).

Table 4. Compressive strength of concretes with and without $\mathrm{SRH}$

\begin{tabular}{|c|c|c|c|c|c|c|}
\hline \multirow{2}{*}{ Mixture } & \multicolumn{6}{|c|}{ Compressive strength (MPa) } \\
\hline & 1 day & 3 days & 7 days & 28 days & 63 days & 91 days \\
\hline \multirow{4}{*}{ Control } & 41.3 & 65.3 & 76.9 & 88.4 & 88.7 & 94.6 \\
\hline & 42.5 & 64.9 & 77.9 & 86.5 & 91.8 & 91.9 \\
\hline & 41.7 & 64.5 & 79.9 & 84.0 & 90.5 & 93.2 \\
\hline & 43.8 & 66.1 & 79.1 & 85.1 & 92.6 & 92.8 \\
\hline SD* & 1.1 & 0.7 & 1.3 & 1.9 & 1.7 & 1.1 \\
\hline \multirow{4}{*}{ 5SRH } & 47.2 & 70.7 & 76.5 & 90.5 & 95.4 & 100.2 \\
\hline & 48.6 & 67.3 & 83.6 & 93.7 & 96.2 & 95.8 \\
\hline & 48.5 & 73.8 & 78.9 & 93.6 & 95.8 & 99.6 \\
\hline & 46.5 & 68.5 & 79.4 & 91.1 & 94.2 & 97.8 \\
\hline SD* & 1.0 & 2.9 & 3.0 & 1.7 & 0.9 & 2.0 \\
\hline \multirow{4}{*}{ 10SRH } & 44.8 & 66.5 & 88.8 & 101.5 & 104.5 & 108.9 \\
\hline & 45.7 & 65.8 & 87.6 & 98.5 & 105.9 & 107.8 \\
\hline & 47.5 & 63.4 & 85.4 & 98.6 & 105.2 & 110.7 \\
\hline & 45.2 & 64.1 & 85.9 & 99.2 & 107.6 & 109.5 \\
\hline SD* & 1.2 & 1.4 & 1.6 & 1.4 & 1.3 & 1.2 \\
\hline
\end{tabular}




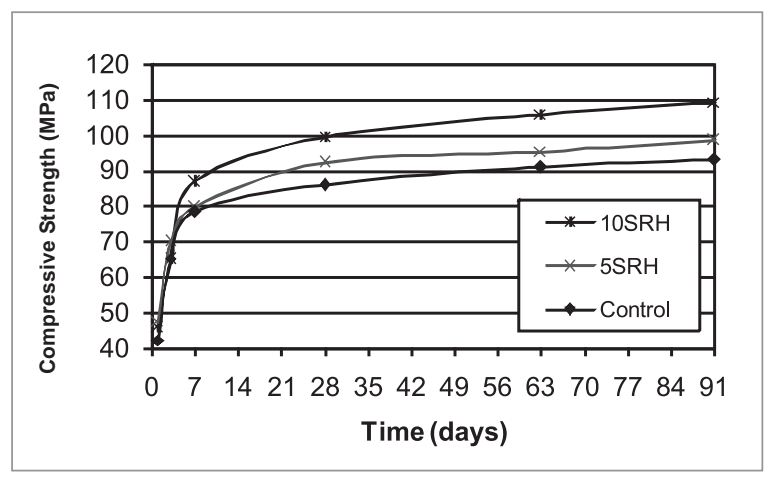

Figure 5. Compressive strength evolution of concretes

Comparison of the data for days of curing time shows that the compressive strength increases when the $\mathrm{SRH}$ is added to concrete, especially as a $10 \%$ replacement for cement. This increase in strength may partially be due to the pozzolanic reaction, filler effect and to a better dispersion of cement particles caused of superplasticizer addition, as reported by early researches (U chikawa et al., 1997; Bui et al., 2005). The high specific area of SRH led to a number of nucleation sites for additional hydration products. It can be seen that the relative increase in compressive strength attains $80 \%$ of the maximum value obtained (91 days) at 7-day curing. Although SRH has been added as a replacement for Portland cement, even at early ages, the compressive strength values increase as compared to reference concrete values. The reasons for early compressive strength development of concretes with SRH are due to fineness, amorphous phase, specific area and degree of reactivity of $\mathrm{SRH}(99.7 \%)$.

\subsection{Splitting tensile strength}

The splitting tensile strength values of concretes with and without SRH after 28 days of curing are show $n$ in Figure 6.

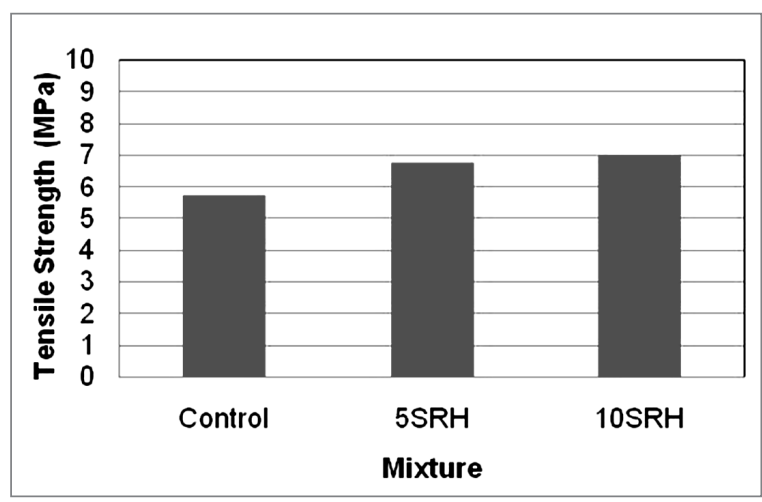

Figure 6 . Splitting tensile strength values of studied concretes
As observed in the compressive strength, the splitting tensile strength values of concretes with SRH were higher than concrete control. It can be clearly seen that the increase is not proportional, since the filler effect is more significant in the compressive strength (Bhanjaa et al., 2005). The increase in splitting tensile strength of concrete with $10 \%$ SRH was $12 \%$ in relation to control concrete.

\subsection{Water absorption}

Water absorption by immersion results are shown in Table 5.

Table 5. Water absorption by immersion of concretes with and without SRH

\begin{tabular}{|c|cc||}
\hline \multirow{2}{*}{ Mixture } & \multicolumn{2}{|c|}{ Water absorption (\%) } \\
\cline { 2 - 3 } & 7 days & 28 days \\
\hline Control & 4.7 & 3.4 \\
5SRH & 4.6 & 4.0 \\
10SRH & 4.4 & 3.9 \\
\hline
\end{tabular}

The effect of SRH is a little significant in concretes at 7 days of curing and, at 28 days, the water absorption values of control concrete was lower as compared to concrete with addition. The water absorption was expected to be lower in concretes with SRH, given that the addition decreases the porosity of materials. Thus, some tests of mercury intrusion porosimetry were carried out in pastes in the same proportion of concretes and the results are shown in Figure 7. The total porosity obtained in pastes with $\mathrm{SRH}$ was $2.31 \%$ and $3.33 \%$ in the control concrete.

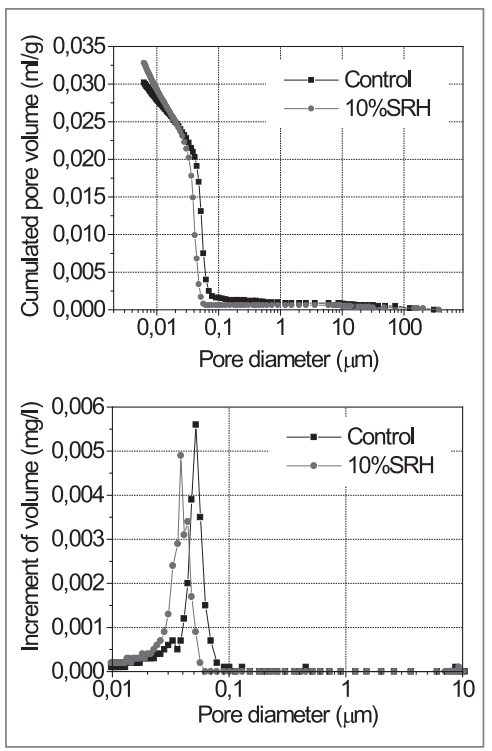

Figure 7. Mercury intrusion porosimetry of pastes with and without SRH 
It can be clearly seen that the material porosity decrease when the addition is incorporated to the concrete; however, the pores of materials are not disconnected, allowing water penetration. According to CEB 192 classification, all the concretes are considered of medium absorption.

\subsection{Water absorption by capillarity}

The results of water absorption by capillarity are shown in Figure 8.

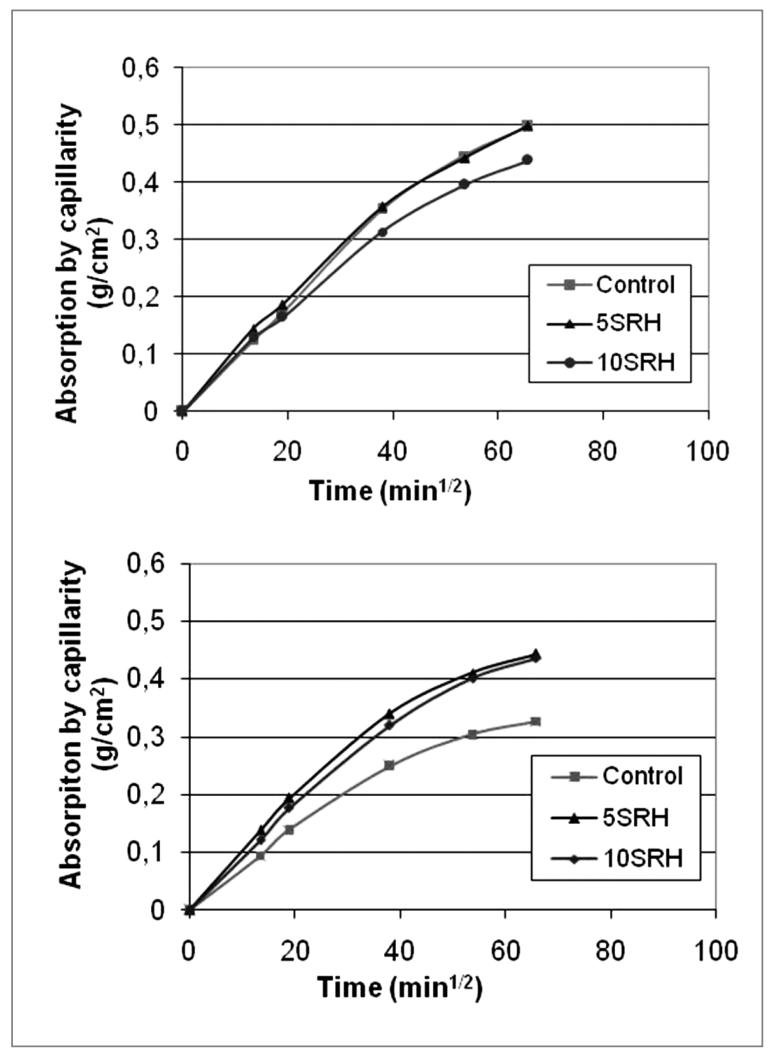

Figure 8 . Water absorption by capillarity of concretes with and without SRH : a) at 7 days and b) at 28 days

According to Figure 7, the results previously presented were proved. The benefits of SRH in concrete were lower than in mechanical properties, since the coefficient of water absorption values progressively increase with the increase in SRH content, especially after 28 days of age. After 7 days of curing, the concrete with $10 \%$ SRH presented a little decrease in coefficient of water absorption values; also, the values of concrete with $5 \% \mathrm{SRH}$ and the control concrete were practically equal. It is observed, from the water absorption data, that $10 \%$ SRH concrete specimen indicate $12 \%$ reduction after 72 hours of test ( $\left.67.5 \mathrm{~min}^{1 / 2}\right)$.

0 ther researches with additions extracted from rice husk, as rice husk ash, reported that highly reactive pozzolana are able to reduce the size of voids in hydrated cement paste, thus making them impermeable even at early ages (Cook, 1986). In this study, there is the pore refinement in $\mathrm{SRH}$ concretes compared to control concrete, however, the reduction in permeability was negligible. Similar results were observed in another research (Liborio, 2000), which can be due to the fact that with rice husk ash, the filler effect of the smaller particles $\left(28.8 \mathrm{~m}^{2} / \mathrm{g}\right)$ in the mixture is higher than the pozzolanic effect. In this study, this fact may have occurred also due to flocculation of SRH particles. As the particles are extremely finer than other additions incorporated into the concrete, there are the agglomerations of the grains, which are not dispersed at the moment of mixture, reducing the surface area to react.

\subsection{Chloride ion penetration}

The results for the test of resistance to penetration of chloride ions into concrete, measured by means of electric charge passed through the specimens (coulomb) at 7 and 28 days, are given in Figure 9. At 7 and 28 days, the control mixture showed the highest value.

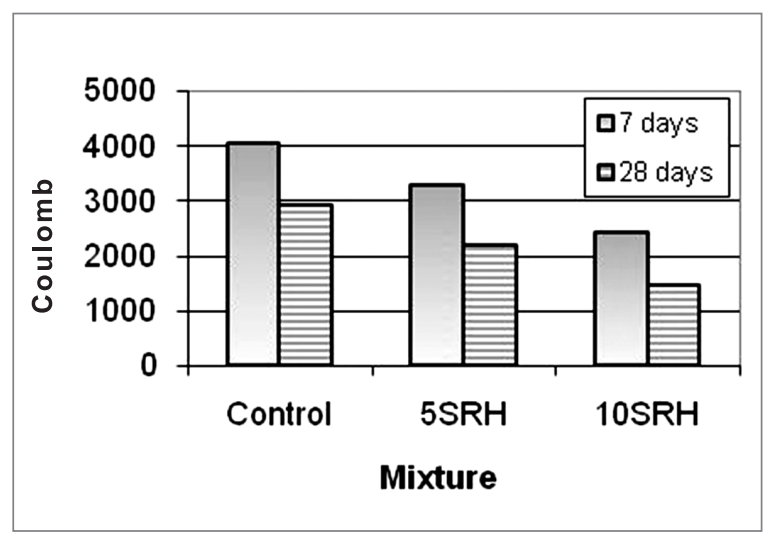

Figure 9. Charge passed of concretes with and without SRH

The substitution of SRH for cement yields a significant reduction in the total charge passed at 7 and 28 days. This reduction amounts to $19 \%$ and $40 \%$ for $5 \% \mathrm{SRH}$ and $10 \% \mathrm{SRH}$, respectively, at 7 days. At 28 days, the same content substitution showed reductions of $24 \%$ and $50 \%$. Thus, although the water penetrates in pores of concrete with addition (according to water absorption test), the chloride ion do not penetrate, because of the small pores diameter. 
Following ASTM C 1202 classification (Table 2 ), the control concrete and $5 \% \mathrm{SRH}$ present moderate risk of chloride ion penetration, while the concrete with $10 \%$ SRH presents a low chloride ion penetration risk.

A study carried out by Bentz et al. (2000) showed that, considering the reduced capillary porosity present at equal degrees of cement hydration in the systems containing silica fume, along with the change in the nanostructure and diffusivity of the $\mathrm{C}-\mathrm{S}-\mathrm{H}$, after equal hydration times, a $10 \%$ addition of silica fume could result in a chloride ion diffusivity more than 15 times smaller than that in a comparable concrete made without silica fume. Although the chloride ion diffusivity has not been verified for the charge passed, it was observed that the values could be even smaller, compared with other researches (Sensale, 2006; U chicawa et al., 1997). Thus, the efficiency of the addition will be even higher if there is a better dispersion of the particles in mixtures.

Even so, the use of SRH reduced the chloride ions ingress, verified by charge passed, indicating that there is an increase in the initiation period in steel corrosion and, consequently, a substantial increase in service life of concrete structures subjected to aggressive environments, such as marine atmosphere.

\section{Conclusions}

For the concrete mixture tested in this study, it was found that:

- The specimens with silica extracted from rice husk showed higher compressive strength values when compared with their equivalent mixture without addition, already at the early ages. The reasons for early compressive strength development of concretes with $\mathrm{SRH}$ are due to fineness, amorphous phase, specific area and degree of reactivity of $\mathrm{SRH}$.

- The concretes with silica extracted from rice husk presented a refinement of pores structure; how ever, the performance in the impermeability properties (water absorption and water absorption by capillarity) was of little significance. It is possible that there was particle flocculation of SRH, reducing the surface area to react.

- In chloride ion penetration, concretes with SRH showed a sharp drop in total charge passed values when compared with the control concrete, reaching reductions of $50 \%$ in $10 \% \mathrm{SRH}$ concrete at 28 days of curing.
In general, the results obtained in this study clearly indicate that the addition of SRH as cement replacement materials provides additional improvements in compressive and splitting tensile strength and resistance to chloride ion penetration. Thus, SRH may be utilized as effective mineral addition for designing durable concrete structures. The best content of silica recommended to be added in a volumetric substitution to the Portland cement is $10 \%$.

\section{Acknowledgements}

The authors would like to thank State of São Paulo Research Foundation for the financial support.

\section{References}

ASTM C1202 (2000), Standard Test Method for Electrical Indication of Concrete's Ability to Resist Chloride Ion Penetration. Annual Book of American Society for Testing M aterials Standards, C04.02.

Bentur A. (2002), Cementitious Materials - Nine Millennia and A New Century: Past, Present, and Future. Journal of Materials in Civil Engineering 2002:14(1):1-22.

Bent DP, Jensen O M, Coats AM and Glasser FP (2000), Influence of silica fume on diffusivity in cement-based materials: I. Experimental and computer modeling studies on cement pastes. Cement and Concrete Research 2000:30(6): 953-52.

Bhanjaa S., Senguptab B. (2005), Influence of silica fume on the tensile strength of concrete. Cement and Concrete Research 2005:35(4):743-747.

Bui DD, Hu J and Stroeven P. (2005), Particle size effect on the strength of rice husk ash blended gap-graded Portland cement concrete. Cement and Concrete Composites 2005: 27(3):357-366.

Comité Euro-International du Béton (1998), Diagnosis and Assessment of Concrete Structures - state of the art report. Bulletin d'Information no 192, Janvier.

Cook J D. (1986), Rice husk ash. In: Swamy RN, editor. Concrete technology and design. Cement replacement material, 3. London: Surrey U niversity Press, 1986, p. 171-95.

Coutinho SJ. (2003), The combined benefits of CPF and RHA in improving the durability of concrete structures. Cement and Concrete Composites 2003: 25(1):51-59. Gastaldine ALG., Isaia GC., Gomes NS., Sperb JEK. (2007), Chloride penetration and carbonation in concrete 
with rice husk and chemical activators. Cement and Concrete Composites 2007:29(3):176-180. Igarashi S., Watanabe A., Kawamura M. (2005), Evaluation of capillary pore size characteristics in high-strength concrete at early ages. Cement and Concrete Research 2005: 35(3):513-519. Liborio J B L., Souza M F., Batista P S., Regiani I., Souza D. P. (2000), Rice Hull-D erived Silica: Appications in Portland Cement and Mullite Whiskers. Materials Research 2000: 3(2):25-30.

Malhotra VM., Mehta PK. (1996), Pozzolanic and cementitious materials. Advanced Concrete Technology, vol. 1. Canada. Gordon and Breach Publ. Mehta PK. (1994), Mineral admixtures for concrete an overview of recent developments. Advances in cement and concrete. In: Proceedings of an Engineering Foundation Conference, U niversity of N ewhampshire, Durham, ASCE; 1994, p. 243-56.

Saraswathy V., Song HW. (2007), Corrosion performance of rice husk ash blended concrete. Construction and Building Materials 2007:21(8):1779-84. Sensale GR. (2006), Strength development of concrete with rice-husk ash. Cement and Concrete Composites 2006:28(2):158-160.

U chikawa H., H anehara S., Sawaki D. (1997), The role of steric repulsive force in the dispersion of cement particles in fresh paste prepared with organic admixture. Cement and Concrete Research 1997:27(1):37-50. 